\title{
Sinococcus qinghaiensis gen. nov., sp. nov., a novel member of the order Bacillales from a saline soil in China
}

\author{
Wen-Jun Li, ${ }^{1} \dagger$ Yu-Oin Zhang, ${ }^{1,2} \dagger$ Peter Schumann, ${ }^{3}$ Xin-Peng Tian, ${ }^{1}$ \\ Yue-Oin Zhang, ${ }^{2}$ Li-Hua $\mathrm{Xu}^{1}$ and Cheng-Lin Jiang ${ }^{1}$ \\ ${ }^{1}$ Laboratory for Conservation and Utilization of Bio-Resources, Yunnan Institute of Microbiology, \\ Yunnan University, Kunming, Yunnan 650091, PR China \\ ${ }^{2}$ Institute of Medicinal Biotechnology, Chinese Academy of Medical Sciences and Peking Union \\ Medical College, Beijing 100050, PR China \\ ${ }^{3} \mathrm{DSMZ}$ - Deutsche Sammlung von Mikroorganismen und Zellkulturen GmbH, Mascheroder \\ Weg 1b, D-38124 Braunschweig, Germany
}

Correspondence

Wen-Jun Li

wjli@ynu.edu.cn

\begin{abstract}
A Gram-positive, non-spore-forming isolate, designated YIM $70212^{\top}$, was isolated from a hypersaline soil sample collected from Qinghai, north-west China. Cells of the isolate were orange-pigmented, motile cocci with multiple flagella. A polyphasic taxonomic investigation was carried out on the isolate. The organism grew at $10-45^{\circ} \mathrm{C}$ and $\mathrm{pH} 7 \cdot 5-11 \cdot 0$, with optimum growth at $28^{\circ} \mathrm{C}$ and $\mathrm{pH} 8 \cdot 0-9 \cdot 5$. Strain YIM $70212^{\top}$ grew optimally in the presence of $10 \% \mathrm{NaCl}, \mathrm{KCl}$ or $\mathrm{MgCl}_{2} \cdot 6 \mathrm{H}_{2} \mathrm{O}$ and growth was observed in 1-25\% $\mathrm{NaCl}, \mathrm{KCl}$ or $\mathrm{MgCl}_{2} \cdot 6 \mathrm{H}_{2} \mathrm{O}$. The peptidoglycan type was $\mathrm{A} 1 \gamma$. Ribose and minor amounts of galactose were detected as the whole-cell sugars. MK-5 was the only menaquinone. The major cellular fatty acids were ai- $\mathrm{C}_{15: 0}(52 \cdot 4 \%)$ and ai- $\mathrm{C}_{17: 0}(26 \cdot 5 \%)$. The DNA G $+\mathrm{C}$ content was $47 \cdot 0 \mathrm{~mol} \%$. Phylogenetic analysis based on $16 \mathrm{~S}$ rRNA gene sequences indicated that strain YIM $70212^{\top}$ formed a distinct lineage within the order Bacillales and was most closely related to members of the genus Marinococcus, showing $16 \mathrm{~S}$ rRNA gene sequence similarity levels of $91 \cdot 0-91 \cdot 4 \%$. Based on the high 16S rRNA gene sequence divergence and differences in phenotypic characteristics, it is proposed that the unknown strain be classified in a novel genus and species with the name Sinococcus qinghaiensis gen. nov., sp. nov.; the type strain of Sinococcus qinghaiensis is YIM $70212^{\top}\left(=\mathrm{KCTC}_{3043^{\top}}=\mathrm{DSM}\right.$ $\left.17008^{\top}\right)$.
\end{abstract}

Recent studies on hypersaline soils in Qinghai Province in north-west China have revealed the presence of a considerable diversity of organisms, constituting moderately halophilic as well as halotolerant bacteria (Li et al., 2004a, 2005a, b, c; Zhang et al., 2005). In this paper, the results are reported of a polyphasic study of another hitherto unknown moderately halophilic strain, designated YIM $70212^{\mathrm{T}}$, which was isolated from a hypersaline soil. The strain grew optimally in media that contained $10 \% \mathrm{KCl}, \mathrm{NaCl}$ or $\mathrm{MgCl}_{2} \cdot 6 \mathrm{H}_{2} \mathrm{O}$. Based on phylogenetic and phenotypic evidence, particularly chemotaxonomic data, the isolate could not be placed in any known genus. It is therefore proposed

†These authors contributed equally to this work.

The GenBank/EMBL/DDBJ accession number for the 16S rRNA gene sequence of strain YIM $70212^{\top}$ is DQ168584.

A table showing the fatty acid composition of strain YIM $70212^{\top}$ and related species and TEMs of cells of strain YIM $70212^{\top}$ are available as supplementary material in IJSEM Online. that the unknown bacterium represents a novel species in a new genus.

Strain YIM $70212^{\mathrm{T}}$ was isolated from a hypersaline soil sample using the dilution plating method. The sample was collected from a region where there are numerous saline lakes with $\mathrm{pH}$ values of $7 \cdot 0-11 \cdot 5$. According to the composition of the soil, which was rich in $\mathrm{KCl}$, a modified SG medium (Sehgal \& Gibbons, 1960) was designed as the isolation medium. It contained $\left(\mathrm{g} \mathrm{l}^{-1}\right): \mathrm{KCl}, 250$; Casamino acids, $7 \cdot 5$; yeast extract, $10 \cdot 0$; trisodium citrate, $3 \cdot 0 ; \mathrm{NaCl}$, $2 \cdot 0 ; \mathrm{MgCl}_{2} \cdot 6 \mathrm{H}_{2} \mathrm{O}, 2 \cdot 0 ; \mathrm{MgSO}_{4} .7 \mathrm{H}_{2} \mathrm{O}, 1 \cdot 0 ; \mathrm{FeSO}_{4} .7 \mathrm{H}_{2} \mathrm{O}$, $0 \cdot 05$; and $\mathrm{MnSO}_{4} \cdot 7 \mathrm{H}_{2} \mathrm{O}, 0 \cdot 0002$. $\mathrm{KCl}$ was sterilized separately and then added to the medium. The plate was incubated at $28^{\circ} \mathrm{C}$ for 2 weeks. The isolate was maintained on ISP2 agar slants that contained $10 \%(\mathrm{w} / \mathrm{v}) \mathrm{KCl}$ at $4{ }^{\circ} \mathrm{C}$ and as glycerol suspensions $(20 \%, \mathrm{w} / \mathrm{v})$ at $-20{ }^{\circ} \mathrm{C}$. Biomass for chemical and molecular systematic studies was obtained from enrichment agar plates of ISP2 medium supplemented with $10 \%(\mathrm{w} / \mathrm{v}) \mathrm{KCl}$ and incubated at $28^{\circ} \mathrm{C}$ for about $4-5$ days. 
Morphology and motility of cells grown for $12-48 \mathrm{~h}$ on ISP2 agar medium supplemented with $10 \% \mathrm{KCl}(\mathrm{w} / \mathrm{v})$ were examined by light microscopy (model $\mathrm{BH} 2$; Olympus) and electron microscopy (JEM-1010; JEOL). For transmission electron microscopy (TEM) observation, cells were negatively stained with $1 \%(\mathrm{w} / \mathrm{v})$ phosphotungstic acid after air-drying. Motility and flagellar arrangement were analysed using semi-solid agar and the staining method of Leifson (1960), followed by light microscopy (model BH 2; Olympus) and TEM. Gram staining was carried out using the standard Gram reaction. The colony colour of the isolate grown on ISP2 agar supplemented with $10 \%(\mathrm{w} / \mathrm{v}) \mathrm{KCl}$ was determined by comparing the cultures with the most suitable colour chips from the ISCC-NBS colour charts (Kelly, 1964). Growth at different temperatures and $\mathrm{pH}$ values was investigated as described by $\mathrm{Xu}$ et al. (2005), but using ISP2 as basic medium. Tolerance of chlorides of sodium, potassium, magnesium and calcium (at 1, 3, 7, 10, $13,15,20,25,28$ and $30 \%$ ) was tested. Metabolic properties were determined using API ID 32E test kits (bioMérieux) according to the manufacturer's instructions, except that microbial suspensions were prepared using sterilized distilled water with $5 \% \mathrm{KCl}$. Other physiological and biochemical tests were performed as described previously ( $\mathrm{Li}$ et al., 2004b, c, 2005a).

Sugar analysis of the whole-cell hydrolysate was carried out as described by Staneck \& Roberts (1974). The diaminopimelic acid isomer was identified in the whole-cell hydrolysate $\left(4 \mathrm{M} \mathrm{HCl}, 100{ }^{\circ} \mathrm{C}, 16 \mathrm{~h}\right)$ by the method of Rhuland et al. (1955). Analyses of polar lipids (twodimensional TLC) and menaquinones (HPLC, MS) was done according to published procedures (Monciardini et al., 2003). Analysis of the cellular fatty acid pattern followed described methods (Miller, 1982) using the MIDI system (Microbial ID).

Extraction and amplification of genomic DNA for $16 \mathrm{~S}$ rRNA gene sequence analysis were carried out as described by $\mathrm{Xu}$ et al. (2003). Multiple alignments with sequences of a broad selection of related species of the order Bacillales and calculations of levels of sequence similarity were carried out using CLUSTAL_X (Thompson et al., 1997). A phylogenetic tree (Fig. 1) was reconstructed using the neighbourjoining method of Saitou \& Nei (1987) from $K_{\text {nuc }}$ values
(Kimura, 1980, 1983). Topology of the phylogenetic tree was evaluated by the bootstrap resampling method of Felsenstein (1985) with 1000 replicates. The DNA G +C content of strain YIM $70212^{\mathrm{T}}$ was determined using the thermal denaturation method (Marmur \& Doty, 1962).

Cells of strain YIM $70212^{\mathrm{T}}$ were aerobic, Gram-positive, non-spore-forming, motile cocci with multiple flagella. Colonies of YIM $70212^{\mathrm{T}}$ were orange, circular, lubricious and opaque on most tested agar media. The strain grew optimally in ISP2 medium supplemented with $10 \%(\mathrm{w} / \mathrm{v})$ $\mathrm{KCl}$ at $28{ }^{\circ} \mathrm{C}$ and $\mathrm{pH} 7 \cdot 5-9 \cdot 0 . \mathrm{KCl}$ could be replaced by $\mathrm{NaCl}$ or $\mathrm{MgCl}_{2} \cdot 6 \mathrm{H}_{2} \mathrm{O}$; the concentration ranges for growth in $\mathrm{KCl}, \mathrm{NaCl}$ and $\mathrm{MgCl}_{2} \cdot 6 \mathrm{H}_{2} \mathrm{O}$ were the same (1-25\%). Strain YIM $70212^{\mathrm{T}}$ could utilize maltose, mannitol, glucose, mannose, fructose, galactose, sucrose, cellobiose and trehalose as carbon sources, but not adonitol, arabinose, arabitol, rhamnose, inositol or sorbitol. Acid was produced from glucose, maltose, sucrose, cellobiose and trehalose. The peptidoglycan type of strain YIM $70212^{\mathrm{T}}$ was $\mathrm{A} 1 \gamma$, based on meso-diaminopimelic acid as diagnostic diamino acid. The phospholipids contained phosphatidylglycerol and diphosphatidylglycerol. In addition, some unidentified lipid components were detected (one phospholipid, one glycolipid and two aminoglycolipids). The only menaquinone was MK-5. The major fatty acids were ai- $\mathrm{C}_{15: 0}(52 \cdot 4 \%)$ and ai- $\mathrm{C}_{17: 0}(26 \cdot 5 \%)$.

Comparison of the almost-complete $16 \mathrm{~S}$ rRNA gene sequence $(1531 \mathrm{bp})$ of strain YIM $70212^{\mathrm{T}}$ with sequences of a wide range of related type strains revealed closest phylogenetic relatedness to Marinococcus halophilus DSM $20408^{\mathrm{T}}$ (91.4\% sequence similarity) and Marinococcus halotolerans YIM $70157^{\mathrm{T}}$ (91.0\% sequence similarity). A distance matrix dendrogram is shown in Fig. 1.

The results of 16S rRNA gene sequence comparisons clearly demonstrated that strain YIM $70212^{\mathrm{T}}$ represents a member of the order Bacillales and is most closely related to members of the genus Marinococcus. However, strain YIM $70212^{\mathrm{T}}$ clearly differed from its closest phylogenetic neighbours of the genus Marinococcus by the number of flagella, acid production from several carbohydrates, hydrolysis of gelatin and casein and enzyme activities, as well as in the menaquinone composition and fatty acid profiles (see Table 1; see also Supplementary Table S1 available in IJSEM Online).

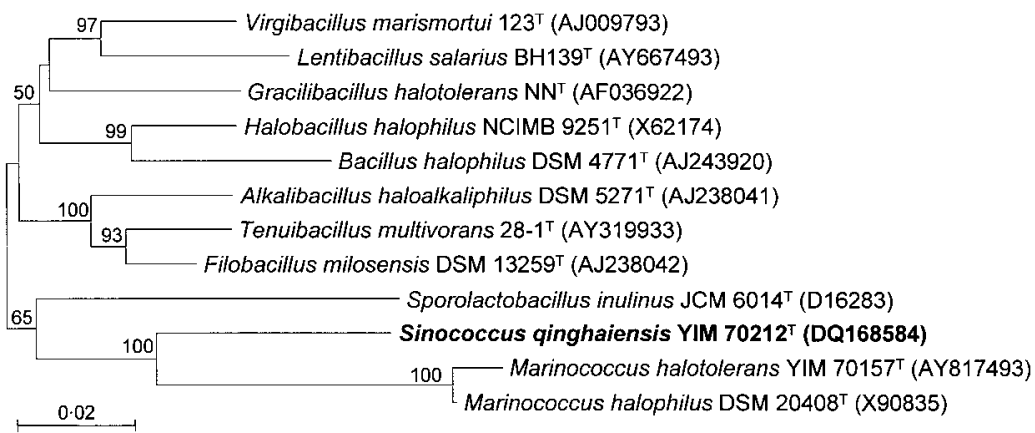

Fig. 1. Neighbour-joining tree showing phylogenetic relationships based on 16S rRNA gene sequences of strain YIM $70212^{\top}$ and other related taxa. Bootstrap values $(50 \%$ and above) are shown in percentages of 1000 replicates. Brevibacillus brevis JCM $2503^{\top}$ was used as an outgroup (not shown). Bar, 0.02 changes per nucleotide position. 
Table 1. Phenotypic characteristics that differentiate strain $\mathrm{YIM} 70212^{\top}$ from closely related taxa

Strains: 1, YIM $70212^{\mathrm{T}}$; 2, M. halophilus DSM $20408^{\mathrm{T}} ; 3$, M. halotolerans YIM $70157^{\mathrm{T}}$. Data were taken from this and previous studies (Hao et al., 1984; Li et al., 2005b).

\begin{tabular}{|c|c|c|c|}
\hline Characteristic & 1 & 2 & 3 \\
\hline Flagella & Multiple & One or two & One or two \\
\hline \multicolumn{4}{|l|}{ Acid production from: } \\
\hline Fructose & - & + & - \\
\hline Cellobiose & + & - & - \\
\hline Mannitol & + & - & + \\
\hline Maltose & + & - & - \\
\hline \multicolumn{4}{|l|}{ Hydrolysis of: } \\
\hline Gelatin & - & + & - \\
\hline Casein & + & + & - \\
\hline \multicolumn{4}{|l|}{ Enzyme activities } \\
\hline Lysine decarboxylase & - & + & + \\
\hline$\alpha$-Galactosidase & - & + & - \\
\hline$\alpha$-Glucosidase & + & + & - \\
\hline$\alpha$-Maltosidase & + & - & + \\
\hline Predominant menaquinone & MK-5 & MK-7 & MK-7 \\
\hline $\begin{array}{l}\text { Major fatty acids } \\
(>10 \% \text { of the total })\end{array}$ & $\begin{array}{c}\text { ai- } C_{15: 0}(52 \cdot 4 \%), \\
\text { ai-C }-C_{17: 0}(26 \cdot 5 \%)\end{array}$ & $\begin{array}{cc}\text { ai- } C_{15: 0} & (45 \%), \\
\text { ai-C } C_{17: 0} & (30 \%), \\
i-C_{16: 0} & (14 \%)\end{array}$ & $\begin{array}{c}\text { ai- } \mathrm{C}_{15: 0}(37 \cdot 4 \%), \\
\text { ai-C } \mathrm{C}_{17: 0}(21 \cdot 1 \%)\end{array}$ \\
\hline
\end{tabular}

Additionally, isolate YIM $70212^{\mathrm{T}}$ formed a separate clade next to $M$. halotolerans and M. halophilus (Fig. 1). Therefore, based on the above phenotypic and genotypic data, it is proposed that isolate YIM $70212^{\mathrm{T}}$ should be classified as a representative of a novel genus and species, for which the name Sinococcus qinghaiensis gen. nov., sp. nov. is proposed.

\section{Description of Sinococcus gen. nov.}

Sinococcus (Si.no.coc' cus. M.L. gen. n. Sinae of China; N.L. masc. n. coccus from Gr. n. kokkos a grain or berry; N.L. masc. n. Sinococcus coccus-shaped microbe isolated from places in China).

Cells are Gram-positive, non-spore-forming, motile cocci with multiple flagella. Strictly aerobic and Gram-positive. Catalase-positive and oxidase-negative. The peptidoglycan type is A $1 \gamma$ (meso-diaminopimelic acid, directly crosslinked). Major cellular fatty acids are ai- $\mathrm{C}_{15: 0}$ and ai- $\mathrm{C}_{17: 0}$. The menaquinone is $\mathrm{MK}-5$. The $\mathrm{G}+\mathrm{C}$ content of genomic DNA is about $47 \mathrm{~mol} \%$. The type species is Sinococcus qinghaiensis.

\section{Description of Sinococcus qinghaiensis sp. nov.}

Sinococcus qinghaiensis (qing.hai.en'sis. N.L. masc. adj. qinghaiensis pertaining to Qinghai, a province of north-west China).

Displays the following properties in addition to those given in the genus description. Cell diameter is about
$0 \cdot 8-1 \cdot 0 \mu \mathrm{m}$ (see Supplementary Fig. S1 in IJSEM Online). Colony colour on most tested media is orange. Colonies are circular, opaque and approximately $1.5-1.8 \mathrm{~mm}$ in diameter after $24 \mathrm{~h}$ at $28^{\circ} \mathrm{C}$. The optimum concentration of $\mathrm{KCl}$ for growth is $10 \%(\mathrm{w} / \mathrm{v})(\mathrm{KCl}$ can also be replaced by $\mathrm{MgCl}_{2} \cdot 6 \mathrm{H}_{2} \mathrm{O}$ or $\mathrm{NaCl}$ ). Optimum growth occurs at $\mathrm{pH} 8 \cdot 0-9 \cdot 5$ and $28{ }^{\circ} \mathrm{C}$. Grows in $1-25 \% \mathrm{KCl}$, $\mathrm{MgCl}_{2} \cdot 6 \mathrm{H}_{2} \mathrm{O}$ and $\mathrm{NaCl}$. Positive for lipase, $\beta$-glucosidase, $\beta$-galactosidase, $\alpha$-glucosidase and casein hydrolysis, but negative for arginine dihydrolase, lysine decarboxylase, ornithine decarboxylase, $\alpha$-galactosidase, $\alpha$-maltosidase, urease, $N$-acetylglucosaminidase, nitrate reduction, gelatin liquefaction, ammonia production, methyl red and Voges-Proskauer tests, milk peptonization and coagulation, growth on cellulose, $\mathrm{H}_{2} \mathrm{~S}$ and melanin production and starch hydrolysis. Maltose, mannitol, glucose, mannose, fructose, galactose, sucrose, cellobiose and trehalose can be utilized as carbon sources; adonitol, arabinose, arabitol, rhamnose, inositol and sorbitol cannot be utilized. Acid is produced from glucose, maltose, sucrose, cellobiose and trehalose. The major whole-cell wall sugar is ribose; galactose is present in minor amounts. Polar lipids contain diphosphatidylglycerol, phosphatidylglycerol and some unidentified components, including one phospholipid, one glycolipid and two aminoglycolipids. The fatty acid profile contains ai- $\mathrm{C}_{15: 0}(52 \cdot 4 \%)$, ai- $\mathrm{C}_{17: 0}(26 \cdot 5 \%)$, i- $\mathrm{C}_{16: 0}$ $(7 \cdot 2 \%), \mathrm{C}_{16: 0}(4 \cdot 8 \%), \mathrm{i}-\mathrm{C}_{14: 0}(2 \cdot 8 \%), \mathrm{C}_{16: 1} \omega 11 c$ alcohol $(2 \cdot 4 \%)$ and $\mathrm{C}_{16: 1} \omega 7 c$ alcohol $(1 \cdot 6 \%)$.

The type strain is strain YIM $70212^{\mathrm{T}}\left(=\mathrm{KCTC} 3943^{\mathrm{T}}=\right.$ DSM $17008^{\mathrm{T}}$ ), isolated from a saline soil sample collected 
from Qinghai in north-west China. The DNA G + C content of the type strain is $47 \cdot 0 \mathrm{~mol} \%$.

\section{Acknowledgements}

This research was supported by the National Basic Research Program of China (Project no. 2004CB719601), the National Natural Science Foundation of China (Project no. 30270004) and Yunnan Provincial Natural Science Foundation (Project no. 2004 C0002Q). W.-J. L. was also supported by the Program for New Century Excellent Talent in University (NCET).

\section{References}

Felsenstein, J. (1985). Confidence limits on phylogenies: an approach using the bootstrap. Evolution 39, 783-791.

Hao, M. V., Kocur, M. \& Komagata, K. (1984). Marinococcus gen. nov., a new genus for motile cocci with meso-diaminopimelic acid in the cell wall; and Marinococcus albus sp. nov. and Marinococcus halophilus (Novitsky and Kushner) comb. nov. J Gen Appl Microbiol 30, 449-459.

Kelly, K. L. (1964). Inter-Society Color Council National Bureau of Standards Color-Name Charts Illustrated with Centroid Colors. Washington, DC: US Government Printing Office.

Kimura, M. (1980). A simple method for estimating evolutionary rates of base substitutions through comparative studies of nucleotide sequences. J Mol Evol 16, 111-120.

Kimura, M. (1983). The Neutral Theory of Molecular Evolution. Cambridge: Cambridge University Press.

Leifson, E. (1960). Atlas of Bacterial Flagellation. London: Academic Press.

Li, W.-J., Tang, S.-K., Wang, D., Xu, L.-H. \& Jiang, C.-L. (2004a). A primary study on biodiversity of moderately halophilic actinomycetes in Xinjiang and Qinghai area. Acta Microbiol Sin 44, 1-7 (in Chinese).

Li, W.-J., Chen, H.-H., Xu, P., Zhang, Y.-Q., Schumann, P., Tang, S.-K., Xu, L.-H. \& Jiang, C.-L. (2004b). Yania halotolerans gen. nov., sp. nov., a novel member of the suborder Micrococcineae from saline soil in China. Int J Syst Evol Microbiol 54, 525-531.

Li, W.-J., Chen, H.-H., Zhang, Y.-Q., Schumann, P., Stackebrandt, E., Xu, L.-H. \& Jiang, C.-L. (2004C). Nesterenkonia halotolerans sp. nov. and Nesterenkonia xinjiangensis sp. nov., actinobacteria from saline soils in the west of China. Int J Syst Evol Microbiol 54, 837-841.

Li, W.-J., Chen, H.-H., Kim, C.-J., Park, D.-J., Tang, S.-K., Lee, J.-C., Xu, L.-H. \& Jiang, C.-L. (2005a). Microbacterium halotolerans sp. nov., isolated from a saline soil in the west of China. Int J Syst Evol Microbiol 55, 67-70.
Li, W.-J., Schumann, P., Zhang, Y.-Q., Chen, G.-Z., Tian, X.-P., Xu, L.-H., Stackebrandt, E. \& Jiang, C.-L. (2005b). Marinococcus halotolerans sp. nov., isolated from Qinghai, north-west China. Int J Syst Evol Microbiol 55, 1801-1804.

Li, W.-J., Schumann, P., Zhang, Y.-Q., Xu, P., Chen, G.-Z., Xu, L.-H., Stackebrandt, E. \& Jiang, C.-L. (2005c). Proposal of Yaniaceae fam. nov. and Yania flava sp. nov. and emended description of the genus Yania. Int J Syst Evol Microbiol 55, 1933-1938.

Marmur, J. \& Doty, P. (1962). Determination of the base composition of deoxyribonucleic acid from its thermal denaturation temperature. J Mol Biol 4, 109-118.

Miller, L. T. (1982). Single derivatization method for routine analysis of bacterial whole-cell fatty acid methyl esters, including hydroxy acids. J Clin Microbiol 16, 584-586.

Monciardini, P., Cavaletti, L., Schumann, P., Rohde, M. \& Donadio, S. (2003). Conexibacter woesei gen. nov., sp. nov., a novel representative of a deep evolutionary line of descent within the class Actinobacteria. Int J Syst Evol Microbiol 53, 569-576.

Rhuland, L. E., Work, E., Denman, R. F. \& Hoare, D. S. (1955). The behavior of the isomers of $\alpha, \varepsilon$-diaminopimelic acid on paper chromatography. J Am Chem Soc 77, 4844-4846.

Saitou, N. \& Nei, M. (1987). The neighbor-joining method: a new method for reconstructing phylogenetic trees. Mol Biol Evol 4, 406-425.

Sehgal, S. N. \& Gibbons, N. E. (1960). Effect of some metal ions on the growth of Halobacterium cutirubrum. Can J Microbiol 6, 165-169.

Staneck, J. L. \& Roberts, G. D. (1974). Simplified approach to identification of aerobic actinomycetes by thin-layer chromatography. Appl Microbiol 28, 226-231.

Thompson, J. D., Gibson, T. J., Plewniak, F., Jeanmougin, F. \& Higgins, D. G. (1997). The CLUSTAL_X windows interface: flexible strategies for multiple sequence alignment aided by quality analysis tools. Nucleic Acids Res 25, 4876-4882.

Xu, P., Li, W.-J., Xu, L.-H. \& Jiang, C.-L. (2003). A microwavebased method for genomic DNA extraction from actinomycetes. Microbiology (Beijing) 30, 82-84 (in Chinese).

Xu, P., Li, W.-J., Tang, S.-K., Zhang, Y.-Q., Chen, G.-Z., Chen, H.-H., Xu, L.-H. \& Jiang, C.-L. (2005). Naxibacter alkalitolerans gen. nov., sp. nov., a novel member of the family 'Oxalobacteraceae' isolated from China. Int J Syst Evol Microbiol 55, 1149-1153.

Zhang, Y. Q., Schumann, P., Li, W. J., Chen, G. Z., Tian, X. P., Stackebrandt, E., Xu, L. H. \& Jiang, C. L. (2005). Isoptericola halotolerans sp. nov., a novel actinobacterium isolated from saline soil from Qinghai Province, north-west China. Int J Syst Evol Microbiol 55, 1867-1870. 